\title{
Assessing the Interrelation between Socio-Economic and Innovative-Technological Development, Institutional Conditions and Urbanization Processes in the Resource-Based Regions Using Dynamic Economic and Statistical Models
}

\author{
Anna R. Semenova, Evgenia B. Bukharova, \\ Irina M. Popelnitskaya, Natalia V. Nepomnyashchaya \\ and Veronica A. Razumovskaya* \\ Siberian Federal University \\ 79 Svobodny, Krasnoyarsk, 660041, Russia
}

Received 12.11.2018, received in revised form 16.11.2018, accepted 19.11.2018

Relying on the current terms and patterns of development of any given region, strategic goals of the country's spatial development and its institutional environment, urbanization impact on the economic and innovative-technological modernization of the territory is not identical. This research aims statistic data-based measurement of quantitative indicators which determine interrelation between the process of urbanization and dimensions for economic, innovativetechnological and socio-cultural development of the regions with resource economy.

In the framework of system analysis urbanized territories are considered as multi-component complex systems. Today's tendencies in the practice of forecasting, planning and monitoring urbanized territories are focused on tackling a multi-criteria and multi-dimensional problem with a complicated system of constraints which is, traditionally, not judgment-based.

This paper observes takes on modeling interrelation between the factors of socio-economic development and the level of urbanization in municipal settlements in the resource region Krasnoyarskiy Krai - and on integrated ranking of urbanized territories based on dynamic changes of these factors.

Keywords: resource-based economy, socio-economic and ecological development of urbanized territories, spatial development, living comfort, dynamic economic and statistical modeling, institutional conditions.

The reported study was funded by Russian Foundation for Basic Research, Government of Krasnoyarsk Territory, Krasnoyarsk Region Science and Technology Support Fund to the research project "Methodological approaches to the classification of modern urbanization

(c) Siberian Federal University. All rights reserved

* Corresponding author E-mail address: buch_53@mail.ru

This work is licensed under a Creative Commons Attribution-NonCommercial 4.0 International License (CC BY-NC 4.0). 
processes in the territories of the resource regions of Siberia and modeling the impact of the level of key urbanization factors on the innovation-technological, economic and socio-cultural development of the region (through the example of the Krasnoyarsk Krai), No 17-12-24013.

Research area: economics.

Citation: Semenova, A.R., Bukharova, E.B., Popelnitskaya, I.M., Nepomnyashchaya, N.V., Razumovskaya, V.A. (2018). Assessing the interrelation between socio-economic and innovative technological development, institutional conditions and urbanization processes in the resource-based regions using dynamic and economic and statistical models. J. Sib. Fed. Univ. Humanit. soc. sci., 12(5), 872-893. DOI: 10.17516/1997-1370-0335.

\section{Introduction}

The outcomes of urbanization for the socio-economic and innovative-technological development of the territories are not identical and rely on the current terms and features of development of any given region; strategy of the country's spatial development as well as its institutional environment. It is resulted primarily from the fact that the development of urbanized territories can be considered as a place of different interest clash:

- Residents who are standing up for their rights for a good and proper life;

- Local business, that's activity is focused on maximizing its profit, sometimes, due to neglecting the population's interests, mainly linked to the ecology;

- Different levels of administration - from the federal one, responsible for strategic priorities, to the local one oriented on tackling some current problems.

On the one hand, the attraction force of the urbanized territories for living there is explained by higher living standards and comfort level, determined by different economic, social, ecological and climatic factors. Also, the concentration and variety of resources in the cities stimulate business to place their productions on such territories owing to the fact that there are extra wide-market scaled impacts and opportunity to combine different production factors (Kolomak, 2014).

On the other hand, given certain conditions, rapid growth of the urban localities is accompanied by negative consequences, since there are some limits in the process of urbanization for certain territories, mainly, within high rates of extensive development of those municipalities, which are determined by resource constraints, given that the last are taken within non-transportable production factors. While, earlier, the concentration of manufactures in cities resulted in an extra outcome for the business development, now such negative issues, as infrastructure overloading, traffic standstill, water supply challenges, environmental problems, production underperformance linked to 
increasing costs due to the rise of prices on land, real estate and work are significantly dominating (Melnikova, 2015; Henderson, 1974; Forrester, 1974). Currently the practice of spatial planning and socio-economic forecasting development for Russian regions and cities lean on contemporary national methods and indicators which often do not reflect the modern world-wide tendencies in regional urbanization and slightly meet that motivation of the population in choosing the place to live. According to OECD reviews of Russia and, in particular, Krasnoyarsk on the development of modern cities demonstrate that due to the process of urbanization the vector of development has shifted from economical to the social one (OECD Territorial Reviews, 2006, 2015). At the same time, as many researchers point out, the processes of urbanization in developed countries rely on diversification in economy and development of new innovative sectors (Krugman, 2011, Neffke, et al., 2011, Ciccone, 2002).

Urbanization in the resource regions has its own specific characteristics. This research has covered the cities of Krasnoyarskiy Krai, territorial application, natural and climatic factors, social indicators, economic specification, degree of economic concentration and diversification as well as institutional conditions for business activity of which are likely to be considered as a pattern for the resource regions of Russia (Bukharova, et al. 2017).

The resource-export pattern of the Russian economy development was formed back to the Soviet time. The Great Campaign to the East of this country — Siberia and the Far East - over energy reserves and natural resources was being accompanied with local exploration of vast territories and creation of urban networks. Transition to a market economy did not change the paradigm of the socio-economic development of Russia within the resource-export pattern, but relied on major vertically integrated companies, investments and institutional support of their monopolistic status in the economy of this country and its resource regions (Kolomak, 2015; Zubarevich, 2015). To a large extent, the townscape and development of municipalities in the resource regions of Siberia are linked to the concentration of extracting players in oil and gas sector, metallurgy, fuel-poer and timber complexes (Mikheeva, 2016).

Krasnoyarskiy Krai represents the second-largest entity of the Russian Federation - $2366797 \mathrm{~km}^{2}$; still, such a wide territory is characterized by a weak population density -1.21 persons $/ \mathrm{km}^{2}$. The spatial system of settlements in the Krai heavily depends on hard climate and natural conditions and the current system of extracting companies as well. The climate is unstable and leaps through the longitudes, that, in turn, impose some burden on comfort living. 


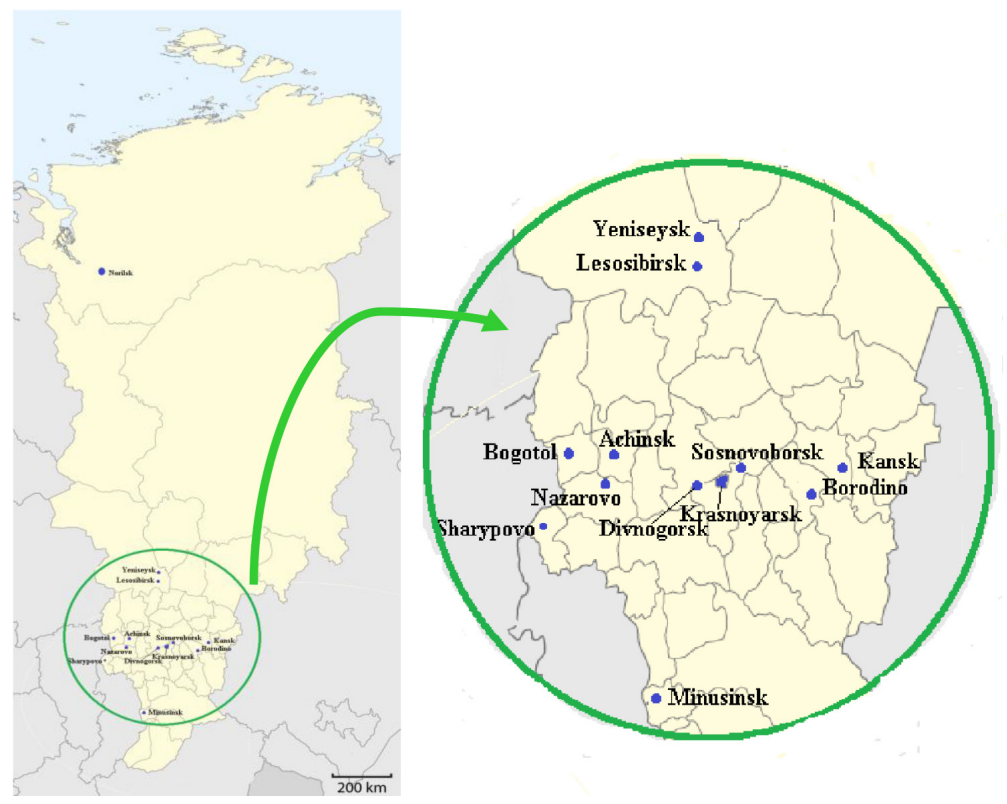

Fig. 1. Layout of the towns in Krasnoyarskiy Krai

The level of urbanization in the Krai is high. According to the data on January 1, 2017, more than $77 \%$ of the Krai's population live in 13 towns with over 50 ths people, whose respond were studied. In this way, it is worth noting that almost all the settlements (excepting Norilsk) cover $10 \%$ of the Krai's territory - more widely used for living and connected to the transport network: the Yenisei River, the eastwest Trans-Siberian Railway and federal highways (Fig. 1). Geographically there is a high degree of asymmetry in the socio-economic development across the territories of Krasnoyarskiy Krai both between its urban districts, municipalities and urbanized areas (Fig. 2).

The Government of the Russian Federation has consistently tried to mitigate the problem of socio-economic differences between the regions (The Presidential Decree, 2017). Still, we have an opposite tendency in deepening of both interregional and intraregional socio-economic asymmetry in the resource regions. This is a fundamental international problem. For example, the study by the international expert group under the guidance of the World Bank highlights that the growth of regional economies will always be unbalanced, and any attempt in providing territorial balance through management tools will fail in achieving this goal, since they preserve socially weak regions and damage the flourishing ones. Still, despite this fact, the government's activity shall seek the economic growth working for the benefit of the whole society (World Development Report, 2009). In this context institutional factors have greater 


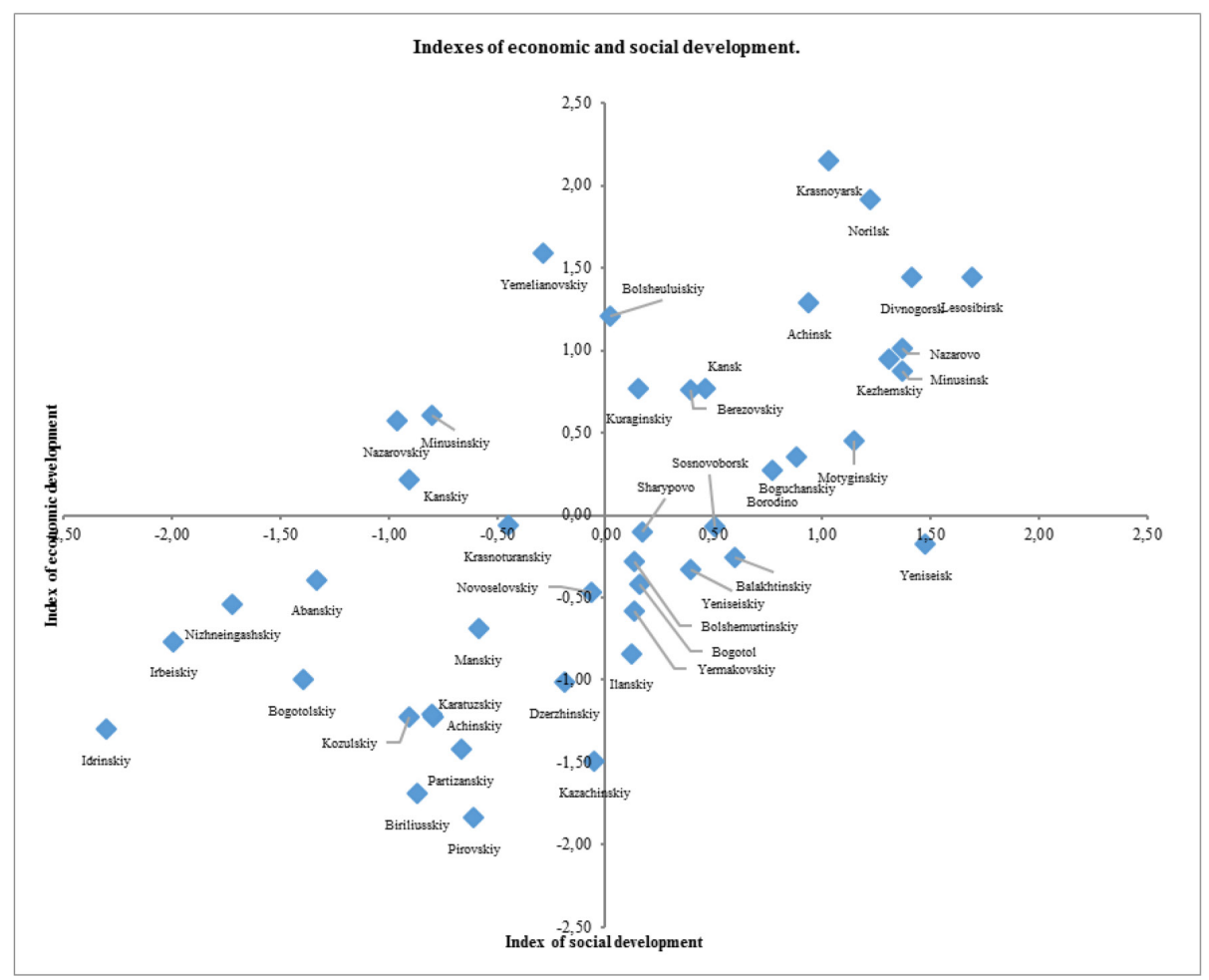

Fig. 2. Circulation of deviations in indexes of social and economic development of urban districts and municipalities in Krasnoyarskiy Krai, of expected values for the region

importance in urban and spatial development. In recent decades, the studies of Russian and foreign researchers on regionalistics have emphasized the problem of institutional influence of the state on urbanization (Rodriguez-Pose, DiCataldo, 2011; Kravchenko, Ageeva, 2017; Rodrik, et al, 2002).

\section{Materials and methods}

1. Dynamic assessment of the interrelation between the indicators of urbanization and indexes of social, economic, innovative-technological development of the urban settlements in Krasnoyarskiy Krai, including the degree of economic diversification and concentration, has been carried out through the built dynamic econometric model. Information basis of this model has been made of current parameters for panel studies which include survey units, period and sampling. In this research we have used a single starting sampling with the urban districts and municipalities of Krasnoyarskiy Krai considered as the survey units. The panel on the development of municipal districts of Krasnoyarskiy Krai cover the period of 2007-2015 (Nepomnyaschaya, Semenova, 2016). 
To analyse the urbanized territories on 13 towns of Krasnoyarskiy Krai Krasnoyarsk, Norilsk, Achinsk, Bogotol, Borodino, Divnogorsk, Yeniseisk, Kansk, Lesosibirsk, Minusinsk, Nazarovo, Sosnovoborsk, Sharypovo - we have figured out the panel data of the corresponding urban districts and their economic, social and environmental indexes have been regarded as indicators.

2. To analyse and forecast a dynamic econometric model of spatial regression (spatial autocorrelation) has been suggested (1). The choice of this regression model, resting on the panel, differs from traditional time-series by the fact that, its variables have a double subindex that reflects the through-time dynamics (1), i. e.:

$y_{i t}=a_{i}+x_{i t}^{\prime} \cdot \beta+\varepsilon_{i t}$

with $i=1, \ldots, n-$ indexes for urban settlements and municipal units; $t=1, \ldots$, $\mathrm{T}$ - timepoints; $x_{i t}^{\prime}$ - independent variables vector (dim vector $k$ ); $k$ - grounds; $y_{i t}$ - dependent variables for an urban settlement or municipal unit $i$ at a timepoint $t$; $\varepsilon_{i t}$ - corresponding error estimation for an urban settlement or municipal unit $i$ at a timepoint $t$.

Whereby the majority of applications analyzing the panel use a single-component model of random error (2):

$$
\varepsilon_{i t}=u_{i}+\delta_{i t}
$$

with $u_{i}$ - invisible specific results; $\delta_{i t}$ - remaining disturbance.

Invisible specific results do not depend on time and demonstrate features of those objects which are excluded from the regression. Remaining disturbance changes in terms of time and objects and can be regarded as a standard random element in regression.

- To soften the asymmetry in the distribution of economic values and to approach regression remainders to normal distribution, there has been a shift to the logs of sampled factors followed by consequent analysis of the regression connections:

a) pooled regression on all the years within the period under consideration and all urban settlements of Krasnoyarskiy Krai. Such model has been assessed through the method of least-squares and excludes the panel structure;

b) regression of time-averaged variables that compares the influence of timeaverage indicators for each municipal unit with the influence of time fluctuations of these indicators against the average ones; 
c) regression model with determined specific results which compares the influence of specific differences of municipal units and dynamic ones. In the research, this model is featured with fixed parameters $-u_{i}$ - invisible specific results, while $\delta_{i t}$ - remaining disturbances represents independent parameters which are normally distributed random values with the expectation of 0 and $\sigma_{\varepsilon}^{2}$ dispersion. In other words, the parameters $\boldsymbol{x}_{i t}^{\prime}$ are supposed as dependent from $\delta_{i t}$ for each $\boldsymbol{i}$ in each period $\boldsymbol{t}$. This model suits the research, since there is a distinctive limited set of $\boldsymbol{n}$ municipal units and urban districts of Krasnoyarskiy Krai and all the hypothesis are limited only by the performance of merely its representatives. In this case, the assessment of specific results $\boldsymbol{a}_{\mathrm{i}}$ for certain urban settlements and municipal units is (3):

$\widehat{\alpha_{l}}=\overline{y_{i}}-\overline{x_{i}^{\prime}} \cdot \hat{\beta}$

The elements of $x_{i t}^{\prime}$ — vector of independent variables - have been formed basing on the statistic indicators in 3 spheres: economy, social sphere and ecology (Nepomnyaschaya, Semenova, 2016):

A) For the economic sphere, independent variables were formed on the basis of economic indicators, the set of which characterizes, on the one hand, the concentration and diversification of the economy of urbanized territories; on the other hand, the efficiency of resource use (labour, capital) in the current technological conditions and investment opportunities innovation and technological development of territories:

- the volume of shipped own-produced goods, own-performed work and services;

- the share of industrial production in the total output of shipped products;

- the share of the average annual number of employees in the resident population;

- labour productivity;

- investments in fixed capital per capita;

- fixed assets;

- the level of fixed assets depreciation;

- capital/labour ratio;

- financial performance (revenues and city budget spending); amount of construction works;

- the amount of agricultural production;

- cargo traffic;

- commissioning the total area of residential buildings per 1000 persons;

- public catering and retail turnover. 
B) As independent variables of the social sphere, more than 20 indicators have been regarded, including:

- demographic indicators: the number of resident population (in pers.); fertility rate,\%o; natural population increase $(+)$ / decrease $(-)$ pers.; positive and negative migration balance of the population, people; the proportion of children and pensioners in the total population; the number of students of educational institutions, including specific divisions (branches), pers;

- incomes of the population: the average wages paid to the employees of organizations, rub; the average pension, rub.; the budget income per person;

- level of recorded unemployment (to the working-aged employable population), as of the end of the period;

- number of persons served by the in-home social services for senior citizens and challenged people, pers;

- volume and quality of services provided to the population: the volume of commercial services per capita, rub; the share of children aged 1 to 6 years who get pre-school educational services in the total number of children aged 1 to 6 years, $\%$; the number of doctors per 10,000 residents; retail trade turnover per capita, rub;

- indicators that determine the level of life comfort: living space per 1 person, $\mathrm{m}^{2}$; the total length of illuminated parts of the streets, roads, embankments, as of the end of the period, km; the number of all types sports facilities; the number of cultural and leisure facilities, units; the number of personal service facilities providing services, units; population density, persons per $\mathrm{km}^{2}$; the total area of residential buildings commissioned in the reporting period by the means of all funding sources, $\mathrm{m}^{2}$; accrued (charged) housing and utility payments per person, rub; housing and communal services actually paid by the population per person, rub; turnover of public catering per capita, rub; the number of recorded crimes, units.

C) The following indicators have been selected as independent variables characterizing environmental situation:

- emissions into the air from stationary and mobile sources;

- water abstraction and discharge;

- waste rate;

- level of climatic changes comfort (frequency of propitious weather, frost-free days per a year, the sum of active temperatures with the daily average +100 , the heating season length, the polar day and night duration, ultraviolet light deficit). 
For all the listed indicators of economic and social sphere, including the environmental ones, the rating has been calculated on each year over the considered period.

4. To assess the level of spatial development in Krasnoyarskiy Krai using the model, the integrated indices of economic development, social sphere and ecological state of municipal districts or urban districts $K_{M O}^{i}$, have been estimated as a normalized sum of ranks on all the vectors of the panel studies (4):

$K_{M O}^{i}=\frac{\sum_{j=1}^{n} r_{i j}-M \cdot n}{\sqrt{D \cdot n}}$

$r_{i j}$ - ranks on $i$-indicator of $j$ - territory state; $M$ - math expectation of the corresponding rank; $D$ - dispersion of the corresponding rank; $n$ - the number of municipal district in Krasnoyarskiy Krai (urban and municipal districts). On the sampled panels $n=13$.

In general, to carry out a comprehensive assessment of the level of economic and social development and environmental well-being in each area of Krasnoyarskiy Krai as a whole, a three-dimensional complex index (5) has been identified:

$$
\bar{K}=\left(K_{\text {экон }}, K_{c}, K_{\text {экол }}\right)
$$

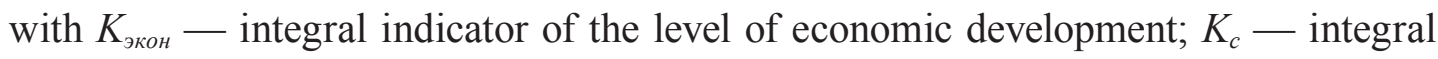
indicator of the level of social development; $K_{\text {экол }}$ - integral indicator of the level of ecological state and living safety of Krasnoyarskiy Krai.

4. The urban settlements in Krasnoyarskiy Krai on socio-economic indicators represent a heterogeneous set of observation objects that makes their total estimation difficult (Fig. 3). To obtain better-quality integrated descriptive characteristics of the observation objects, multidimensional classification of data has been made; the set of towns has been also divided into more homogeneous clusters according to certain features.

The "Euclideandistances" clustering has allowed us to identify sustainable clusters for the entire observation period. The largest and most industrialized settlements have been classified into two separate clusters: Krasnoyarsk and Norilsk (Fig. 4). The other towns have been divided into relative clusters according to the level of their socioeconomic development.

The panel's hierarchical clustering is presented in the form of dendrogram, which, on the strength of connection between the observation objects, allows suggesting three 


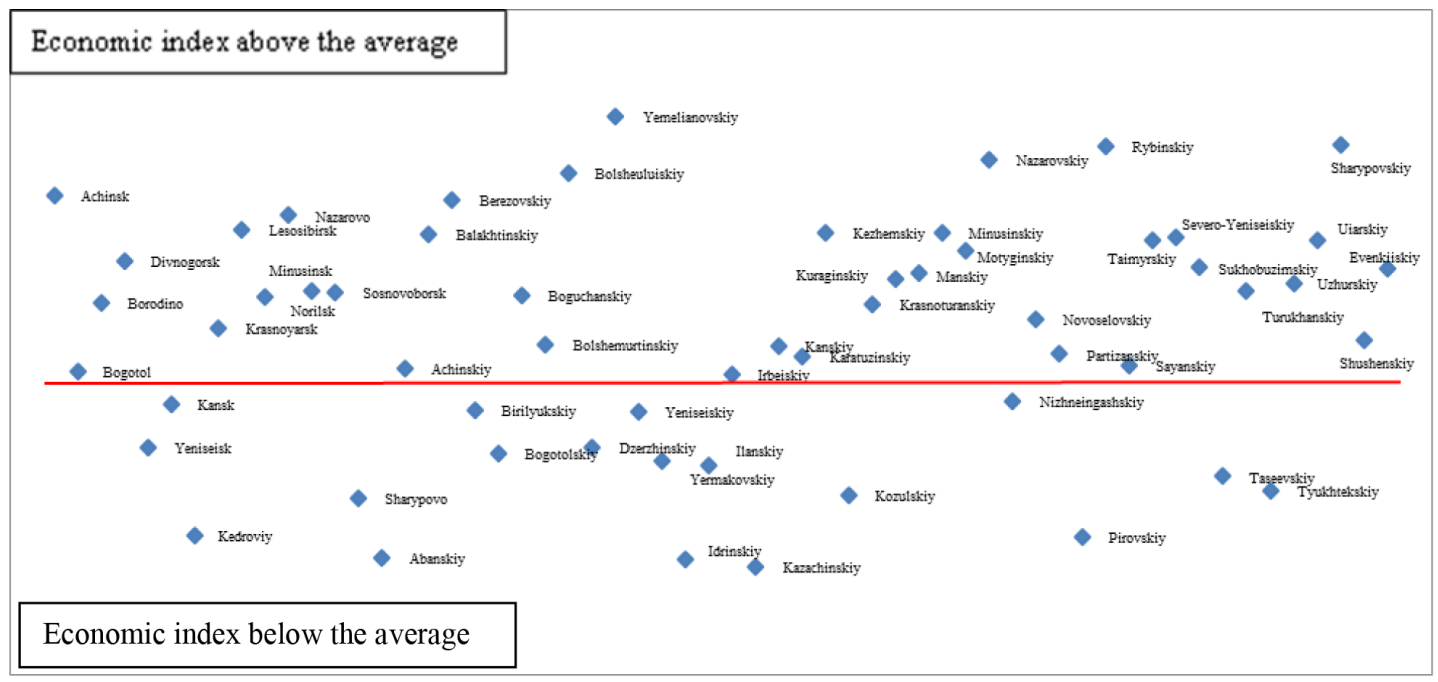

Fig. 3. Distribution of municipal and urban districts in Krasnoyarskiy Krai on integral indicator of the level of economic development in 2014

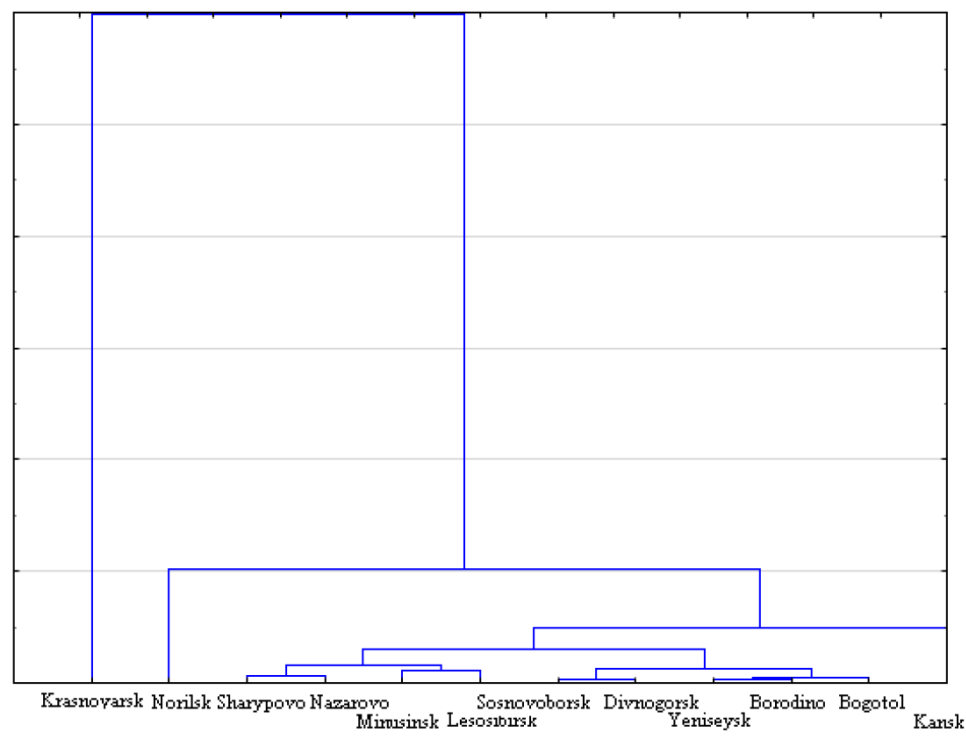

Fig. 4. Dendrogram of urban districts in Krasnoyarskiy Krai

clusters (Fig. 4). The multi-facet grouping through the k-averages method has proved this assumption with a high probability (significance point $\mathrm{p}<0.01$ ).

\section{Results}

1. The volume of shipped own-produced goods, performed works done and services performed have been considered as the result factor characterizing the local economic 
Table 1. Volume of shipped own-produced goods, works done and services performed, on towns

\begin{tabular}{|l|r|r|r|l|r|r|r|}
\hline \multicolumn{1}{|c|}{ Towns } & \multicolumn{1}{c|}{ Mean } & \multicolumn{1}{c|}{ Std. Dev } & \multicolumn{1}{c|}{ Freq. } & Towns & \multicolumn{1}{c|}{ Mean } & \multicolumn{1}{c|}{ Std. Dev } & Freq. \\
\hline Achinsk & 29876929,00 & 4199900,20 & 8,00 & Lesosibirsk & 8687095,80 & 790997,79 & 8,00 \\
\hline Bogotol & 826080,64 & 338196,75 & 8,00 & Minusinsk & 4323944,40 & 1106149,90 & 8,00 \\
\hline Borodino & 6326276,70 & 1940905,30 & 8,00 & Nazarovo & 11896740,00 & 3066186,80 & 8,00 \\
\hline Divnogorsk & 8465916,40 & 2976663,70 & 8,00 & Norilsk & 342400000,00 & 50699810,00 & 8,00 \\
\hline Yeniseisk & 1742812,30 & 554497,48 & 8,00 & Sosnovoborsk & 2134510,70 & 995612,26 & 8,00 \\
\hline Kansk & 4062227,10 & 816814,55 & 8,00 & Sharypovo & 2117866,70 & 965326,37 & 8,00 \\
\hline Krasnoyarsk & 323600000,00 & 104100000,00 & 8,00 & Total Mean & 57420392 & $1.222 \mathrm{e}+08$ & 104 \\
\hline
\end{tabular}

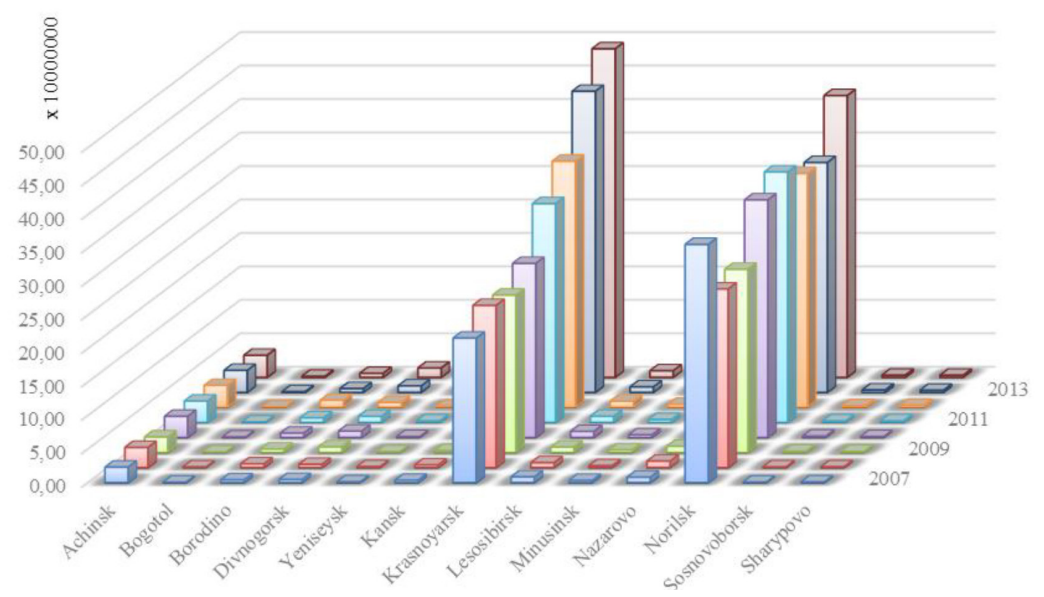

Fig. 5. Volume of shipped own-produced goods, work done and services performed, thousand rubles

sphere. For the selected urbanized areas, the average values for the period and standard deviation are presented in Table 1 and in Fig. 5.

The constructed regression models for the economy of urbanized areas of Krasnoyarskiy Krai have evidenced industrially developed production. Building the pooled regression, regression with determinate and random results on the towns of Krasnoyarskiy Krai has showed the dependence of the volume of shipped products (lvar96) on the share of industrial production (lvar98), the share of the average annual number of workers (lvar100), labour productivity (lvar102), transport fixed assets (lvar111) and budget expenditures (lvar119).

At the same time, the greatest contribution to the regression equation made through different ways of construction has been given by the "labour performance" 


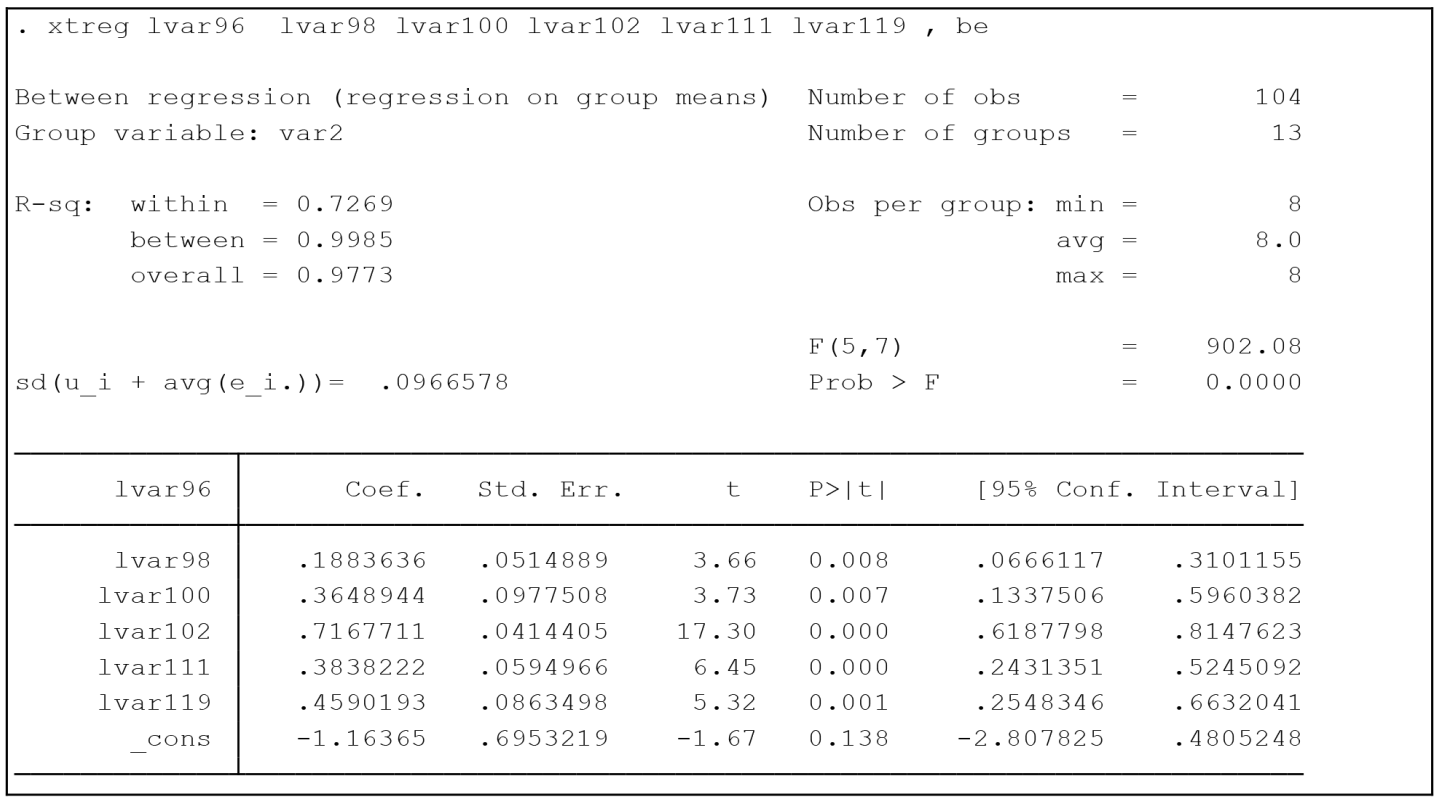

Fig. 6. Regression "between" in economic sphere

Table 2. Total number of resident population, on average over the period, on towns

\begin{tabular}{|l|r|r|r|l|r|r|r|}
\hline \multicolumn{1}{|c|}{ Towns } & \multicolumn{1}{c|}{ Mean } & \multicolumn{1}{c|}{ Std. Dev } & \multicolumn{1}{c|}{ Freq. } & Towns & \multicolumn{1}{c|}{ Mean } & Std. Dev & Freq. \\
\hline Achinsk & 110203.5 & 1756.062 & 8 & Lesosibirsk & 67179.625 & 2074.1676 & 8 \\
\hline Bogotol & 21226.875 & 547.14883 & 8 & Minusinsk & 71400.875 & 1911.0409 & 8 \\
\hline Borodino & 17585.75 & 995.91978 & 8 & Nazarovo & 52542.25 & 884.33684 & 8 \\
\hline Divnogorsk & 33456.25 & 1298.8268 & 8 & Norilsk & 188329.38 & 15041.253 & 8 \\
\hline Yeniseisk & 18774.5 & 248.37414 & 8 & Sosnovoborsk & 32842.5 & 2369.8587 & 8 \\
\hline Kansk & 94988.5 & 2901.6814 & 8 & Sharypovo & 48972.5 & 1713.4809 & 8 \\
\hline Krasnoyarsk & 983875.5 & 40404.311 & 8 & Total & $\mathbf{1 3 3 9 5 2 . 1 5}$ & $\mathbf{2 5 0 9 9 7 . 2 3}$ & $\mathbf{1 0 4}$ \\
\hline
\end{tabular}

indicator, which points out that outdated industrial production technologies, in some cases located within the urban areas, require modernization.

2. Resident population has been regarded as the resulting indicator for the social sphere. In the sampled urban territories, the average values for the studied period and standard deviation are presented in Table 2 in Fig. 7.

The analysis of pooled regression, regressions with deterministic and random effects for the towns of Krasnoyarskiy Krai has demonstrated a steady dependence of the number of resident population on the indicators that determine the quality of life. Thus, continuous regression over the entire time period and all settlements, which excludes the panel data structure and is estimated with the simple least-squares method, determines the number of population through such indicators as: "living space per 1 


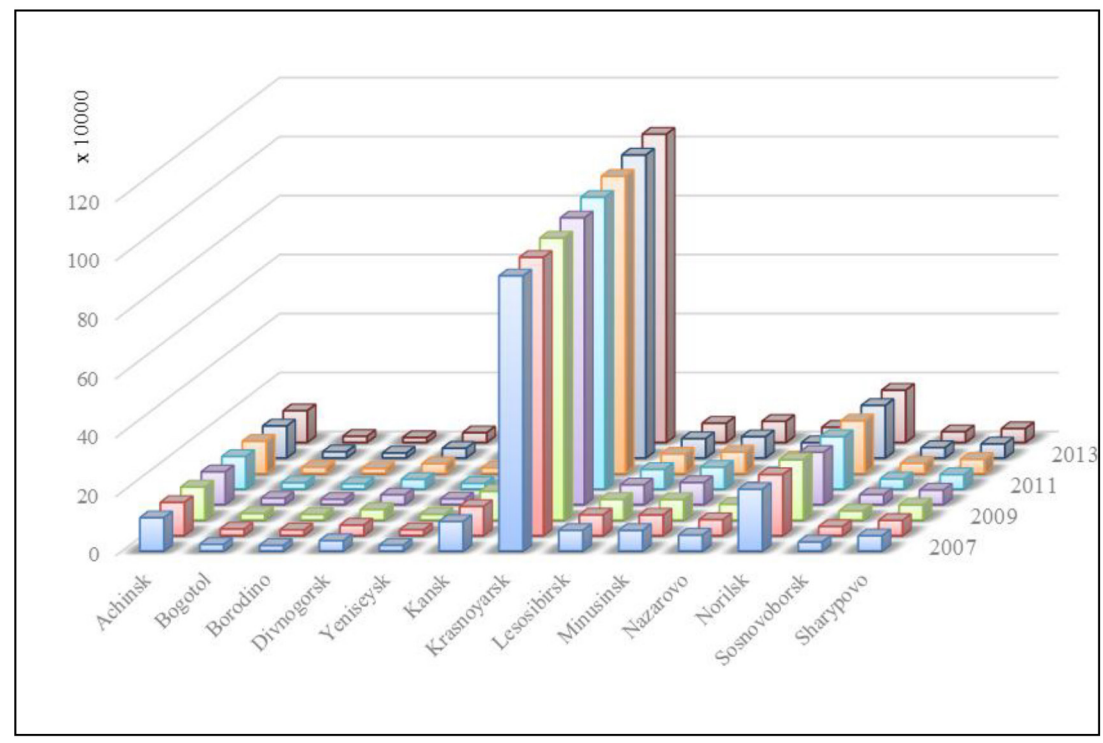

Fig. 7. Resident population number, on average over the period

person", "number of students of general educational institutions", "number of cultural and leisure time organizations", "number of personal service facilities providing services", "positive/negative migration balance", "number of recorded crimes ".

The formation of regression model for the panel data with deterministic effects has showed that in these urban areas the population number depends primarily on "volume of commercial services per capita" (lvar5), "retail trade turnover per capita" (lvar9), "number of students of general educational institutions" (lvar17), "number of cultural and leisure-time organizations" (lvar19), "number of personal service facilities providing services" (lvar20), "positive/negative migration balance" (lvar23), "number of recorded crimes" (lvar28), "number of sport facilities" (lvar29). The value of R-sqbetween is 0.9952 that means that a change in the time average indices for each town has more significant effect on the variables, than temporal variations of these indicators to the average relatively.

The "within" regression - a model presented in terms of deviations from the time-averaged variables - allows for each sampled object to take into account the actual, but invisible, heterogeneity. In this case, the model looks like.

The assessment of regression model with random effects has demonstrated the following.

3. Analysis of Krasnoyarsk Krai towns rating demonstrated an average positive correlation between economic and social indicators ( $R s p=-0.58, p<0.05)$, a weak negative correlation between environmental and social indicators $(\mathrm{Rsp}=-0.38$, 


\begin{tabular}{|c|c|c|c|c|c|c|c|}
\hline - xtreg lvar21 & lvar5 lvar9 & lvar17 lvar1 & 9 Ivar22 & $1 \operatorname{var} 231$ & Ivar28 lvar2 & 29 & be \\
\hline Between regres & ion (regress & ion on group & means) & Number $c$ & of obs & $=$ & 104 \\
\hline Group variable & var2 & & & Number $c$ & of groups & $=$ & 13 \\
\hline R-sq: within & $=0.1270$ & & & Obs per & group: $\min$ & $=$ & 8 \\
\hline between & $=0.9997$ & & & & $\operatorname{avg}$ & $=$ & 8.0 \\
\hline overall & $=0.8972$ & & & & $\max$ & $=$ & 8 \\
\hline & & & & $F(8,4)$ & & $=$ & 1440.58 \\
\hline $\operatorname{sd}\left(u_{-} i+\operatorname{avg}(e\right.$ & $i).)=.0353$ & 953 & & Prob > & & $=$ & 0.0000 \\
\hline $1 \operatorname{var} 21$ & Coef. & std. Err. & t & $P>|t|$ & {$[95 \%$ Conf } & f. & Interval] \\
\hline lvar5 & .0871566 & .0191393 & 4.55 & 0.010 & .0340174 & & .1402959 \\
\hline $1 \operatorname{var} 9$ & .7899215 & .1776114 & 4.45 & 0.011 & .2967932 & & 1.28305 \\
\hline $1 \operatorname{var} 17$ & .7974074 & .0984314 & 8.10 & 0.001 & .5241179 & & 1.070697 \\
\hline $1 \operatorname{var} 19$ & .19507 & .0572508 & 3.41 & 0.027 & .0361163 & & .3540238 \\
\hline 1 var22 & -.1982029 & .0339378 & -5.84 & 0.004 & -.2924293 & & -.1039766 \\
\hline 1var23 & .101005 & .0311427 & 3.24 & 0.032 & .0145389 & & .1874711 \\
\hline 1 var28 & -.3420699 & .0633869 & -5.40 & 0.006 & -.51806 & & -.1660797 \\
\hline $1 \operatorname{var} 29$ & .2704076 & .0577712 & 4.68 & 0.009 & .1100092 & & .4308061 \\
\hline${ }_{-}^{\text {cons }}$ & -4.321722 & 1.348892 & -3.20 & 0.033 & -8.066848 & & -.5765963 \\
\hline
\end{tabular}

Fig. 8. Regression "between" in social sphere

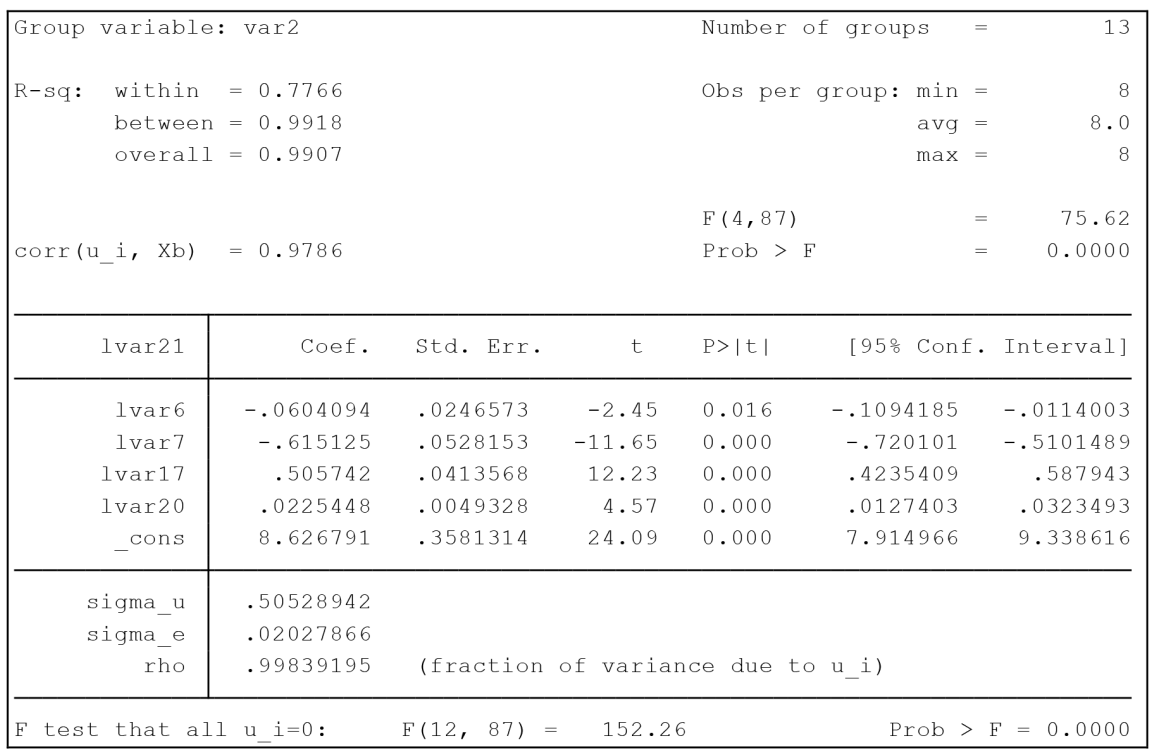

Fig. 9. Regression "between" in social sphere

$\mathrm{P}<0.05), \quad$ andastrongnegativecorrelationbetweeneconomicandenvironmentalindicat ors $(\mathrm{Rsp}=-0.71, \mathrm{p}<0.05)$. Thus, it can be noted that the anthropogenic impact on the environment of towns is associated with enterprises, most of which are virtually located in the residential area. The cumulative effect of the environmental lever, both in the sphere of the town formation economy, and in the political and social spheres 


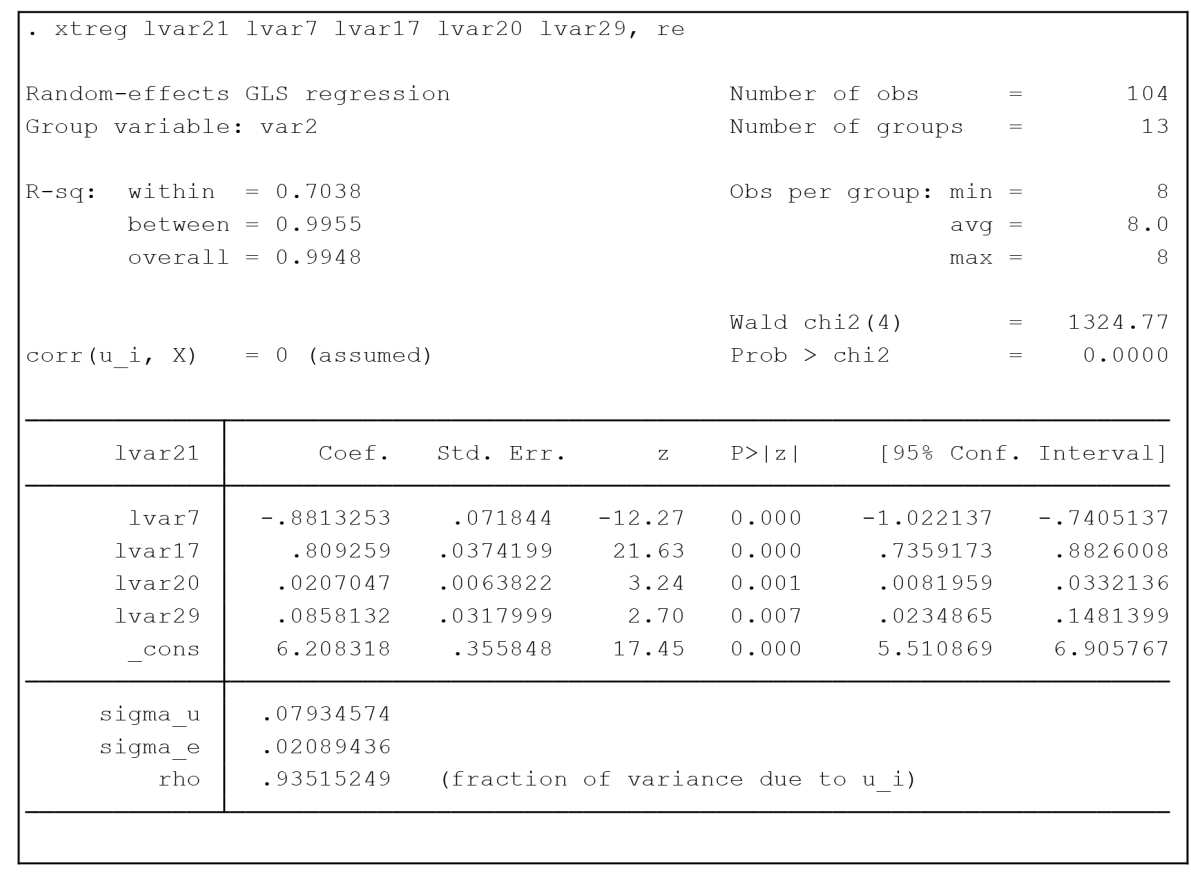

Fig. 10. Regression with random effects in social sphere

of densely populated areas, ultimately, significantly affects their competitiveness (Nepomnyaschaya, Semenova, 2016).

4. A big contribution to negative environmental indicators is made by the thermal power stations, as according to the climatic indexes most of the towns belong to the hypo comfort and pre-comfort territories and, therefore, the heating season lasts from 8 to 9 months a year. Norilsk is an extreme territory, based on the separate indicators the town of Minusinsk can be attributed to a comfortable area of residence.

Along with stationary sources, mobile sources (transport) of pollution significantly contribute to air pollution. For a number of the Krai' towns, such as Sharypovo, Minusinsk, Sosnovoborsk and Kansk, the contribution of mobile sources to atmospheric air pollution exceeds the contribution of stationary ones, in Krasnoyarsk and Borodino these indicators are commensurable (see Fig. 11), which should be taken into account in the process of the urban environment planning.

5. Based on the model analysis results, an average rating based on economic, social and environmental indicators, the results of which are given in Table 3, was determined for 13 towns.

The qualitative analysis of the results of modelling on various modifications of the spatial regression dynamic econometric model has made it possible to identify the main critical factors of economic development, regarding sectoral structure, concentration 


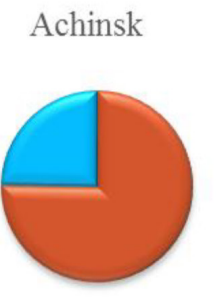

Lesosibirsk

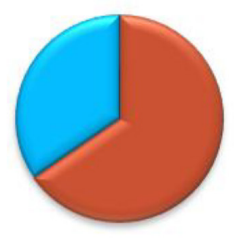

Sharypovo

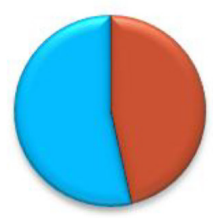

Kansk

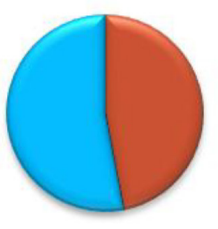

Minusinsk

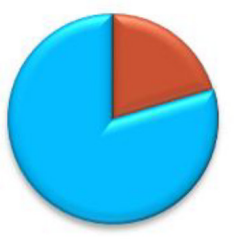

Borodino

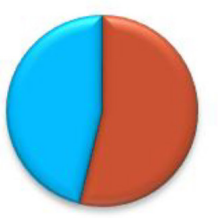

घ stationary $\mathbf{a m o b i l e}$
Krasnoyarsk

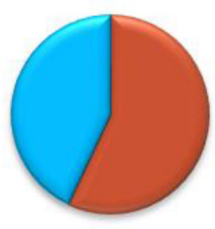

Nazarovo

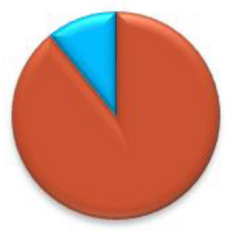

Norilsk

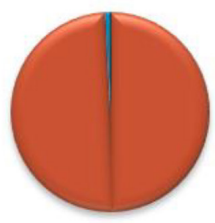

Fig. 11. Contribution of stationary and mobile air pollution sources

Table 3. Average rating of the towns of Krasnoyarsk Krai during the period from 2007 to 2014

\begin{tabular}{|l|c|c|c|}
\hline \multicolumn{1}{|c|}{ Town } & $\begin{array}{c}\text { Average rating } \\
\text { of social indicators }\end{array}$ & $\begin{array}{c}\text { Average rating } \\
\text { of economy }\end{array}$ & $\begin{array}{c}\text { Average rating of } \\
\text { environmental indicators }\end{array}$ \\
\hline Achinsk & 159 & 116 & 77 \\
\hline Bogotol & 109 & 79 & 23 \\
\hline Borodino & 133 & 93 & 63 \\
\hline Divnogorsk & 144 & 127 & 31 \\
\hline Yeniseisk & 146 & 60 & 55 \\
\hline Kansk & 114 & 98 & 86 \\
\hline Krasnoyarsk & 200 & 158 & 62 \\
\hline Lesosibirsk & 141 & 119 & 44 \\
\hline Minusinsk & 150 & 98 & 92 \\
\hline Nazarovo & 132 & 115 & 90 \\
\hline Norilsk & 175 & 142 & 40 \\
\hline Sosnovoborsk & 151 & 89 & 41 \\
\hline Sharypovo & 159 & 73 & \\
\hline
\end{tabular}


and diversification of the economy and to assess their changes in the connection with the key factors of urbanization.

\section{Conclusion}

Economic growth in the Krai is taking place due to the development of industrial production and is ensuring the improvement of social conditions and comfortable living on the urban areas average in this region. However, in the context of urbanized territories, economic development is sharply differentiated, which recently has led to even higher level of the intraregional asymmetry in the socio-economic situation in the towns and municipalities. This is due to the current industrial structure of production and settlements, investment strategies of the companies and the state, financial and economic constraints associated with the budget deficit in the majority of urban entities and municipal districts, institutional conditions that ensure business activity and implementation of territorial management principles. The economic and statistical analysis of the panel data on urban entities and the analysis of the results of variants calculations through the dynamic econometric model allow us now to draw the following conclusions:

1. Urban districts (excepting Bogotol) are characterized by a higher level of socioeconomic development, exceeding the average regional level (see Fig. 2). The highest level of socio-economic status is in Krasnoyarsk and Norilsk, which cover a large territory and have a high level of industrial production concentration.

2. The regional economy is characterized by a high degree of monopolization in the raw materials and infrastructure sectors. Each ten large vertically integrated companies and publicly owned companies account for more than $70 \%$ of production, which imposes market barriers for the development of small and medium-sized businesses both in large, medium and small settlements. Opportunities to form economic and financial potential in small and medium towns are extremely low, since the activity of such companies is concentrated mainly in the cities of Krasnoyarsk and such agglomerations as Norilsk and Achinsk or in the nonurbanized territories.

3. In most towns, there is an extremely low level of economic diversification. For example, coal industry dominates in the production structure of such towns as Borodino and Sharypovo; in Norilsk - nonferrous metallurgy; in Achinsk - oil refining industry; in Lesosibirsk — forest industry. For other small and medium settlements in this region, the types of economic activities are dominated by the 
services sector: these are mainly trade, consumer and public services. A high level of economic diversification is observed only in Krasnoyarsk.

4. The state policy of economic development of the region and the strategy of companies are mainly aimed at developing new centres and sectors of the resource economy. For the last 10-15 years, most of the private investment and state capital investments are attributed to the implementation of leading investment projects on the development of new natural resources, as well as the creation of production and transport infrastructure in non-urbanized areas adjacent to the deposits. These are, for example, such wide-scaled investment projects as: the Vankor project on the development of oil and gas fields (Turukhanskiy district); the development project for the Lower Angara region (Boguchanskiy district, electricity power engineering, aluminum production, forestry and timber processing); the development of gold mining in the North-Yenisei district. In fact, now the formation of new industrial centres of economic growth in the province is being under its way with the prospect of further urbanization of the territories and creation of new small settlements.

5. It is necessary to state that, in general, in Krasnoyarskiy Krai, as in the resource region, many small and medium towns are not the centres of investment attraction and new activities development. The exceptions are the cities of Norilsk, Borodino, Sharypovo and Lesosibirsk. The high level of urbanization in Norilsk, combined with unique copper-nickel ore deposits, is an example of attracting large volumes of private business investment in the expansion and technological modernization of non-ferrous metal production. The economic development in Borodino and Sharypovo occurs due to the involvement of coal production and in Lesosibirsk - of forest industry. All these examples highlight the tendency to increasing concentration of the resource industries in these urbanized areas.

6. The cluster analysis of the calculations based on the dynamic economic and statistical model has showed an increase in the socio-economic asymmetry and decrease in homogeneity of the relationship between small and medium settlements with adjacent non-urbanized municipal districts. One of the key reasons for this phenomenon lies in the system of institutional vertical and horizontal interactions between territorial entities of different levels (country, federation, municipality). In fact, the system of intergovernmental relations is built only vertically and is aimed at withdrawing the majority of the incomes of urban districts and municipal districts to higher level budgets. At the same time, over the past decade, at the federal level, the terms on empowering the federation's subjects and municipal entities to a level 
without securing supporting sources of income have changed. Due to this, most of the settlements in the region have faced budget deficits, and in these conditions they do not have sufficient funds for economic development. Horizontal consolidation of financial development sources between the municipalities in solving economic and social problems in the legal field is being poorly regulated.

7. Another significant reason that has a negative impact on the economic development of the settlements and ensuring the high level of urbanization is new institutional norms in the field of taxation of large companies. Thus, the introduction of a taxation mechanism for consolidated groups of taxpayers, and this mainly concerns vertically integrated companies, has led to a sharp decrease in the taxable base and incomes of the budgets of the regions, federation subjects and municipalities.

8. The scenario calculations based on the model has evidenced that under the current conditions the economic and social situation of small and medium settlements of the region will deteriorate, leading to increased outflow of the population, especially of young people.

9. The results of calculations based on the model have also confirmed the key role of Krasnoyarsk and the emerging Krasnoyarsk agglomeration in the economic and innovative technological development of the region. Krasnoyarsk has diversified economy, which includes highly technological production; developed innovation services; large universities that train high-calibre staff in a wide range of specialties and areas; federal research centres. In cooperation with Zheleznogorsk, ClosedAdministrative Territorial Unit, a cluster has been formed on the basis of existing enterprises in the field of space technology, nuclear industry and precision engineering. The analysis of the results has indicated the increasing positive dynamics of the influence of Krasnoyarsk on the socio-economic situation of small cities and non-urban areas with the Krasnoyarsk agglomeration. At this time, the work is being continued on the development of mechanisms and institutional conditions for the creation and operation of the Krasnoyarsk agglomeration.

10. The proposed approach to assessing the relationship between urbanization and socio-economic development of the region based on panel studies and dynamic economic and statistical model, on the one hand, provides statistically significant results. On the other hand, the obtained results are confirmed by the content interpretation in accordance with the real processes occurring in the region. The model can be used to assess the inertial scenarios of urban development in the system of interaction of municipalities in large regions for short-term forecasting. 


\section{References}

Bukharova, E.B., Samusenko, S.A., Semenova, A.R. (2017). Integrated assessment of economic security in a resource region, In Regional Research of Russia 7, (3), 237-248.

Ciccone, A. (2002). Agglomeration Effects in Europe, In European Economic Review, 46 (2), 213-227.

Forrester, J.W. (1974). Dinamika razvitiia goroda [Urban Dynamics]. Moscow: Progress.

Henderson, J.V. (1974). The size and types of cities, In American Economic Review, 64 (4), 640-656.

Kogler, D., Essletzbichler, J., Rigby, D. (2017). The evolution of specialization in the EU15 knowledge space, In Journal of Economic Geography, 17(2), 345-373.

Kolomak, E.A. (2014). Razvitie gorodskoi sistemy`Rossii: tendentsii i faktory [Development of urban systems in Russia: trends and factors], In Voprosy ekonomiki [Problems of Economy], 10, 82-96.

Kolomak, E.A. (2015). Evolution of spatial distribution of economic activity in Russia, In Regional Research of Russia, 5(3), 236-242.

Kravchenko, N.A., Ageeva, S.D. (2017). Diversification of the economy: institutional aspects, In Journal of Institutional Studies, 9 (4), 53-67.

Krugman, P. (2011). The new economic geography, now middle-aged, In Regional Studies, 45, 1-8.

Melnikova, L.V. (2015). Razmery gorodov, effektivnost i ekonomicheskii rost [City size, performance and economic growth], In Zhurnal EKO [ECO Journal], 7, 5-19.

Mikheeva, N.N. (2016). The diversification of regional economic structure as a growth strategy: pros and cons, In Region: Economics and Sociology, 4, 196-217.

Neffke, F., Henning, M. and Boschma, R. (2011). How do regions diversify over time? Industry relatedness and the development of new growth paths in regions, In Economic Geography, 87(3), 237-265.

Nepomnyaschaya, N.V., Semenova, A.R. (2016). Methodological approaches to the formation of the applied models for panel data analysis to forecast the resource region economic development under conditions of spatial asymmetry (exemplified by Krasnoyarskiy Krai), In Journal of Siberian University. Humanities, 11, 2632-2639.

OECD (2006). Territorial Reviews: Competitive Cities in the Global Economy. Paris: OECD.

OECD (2015). Territorial Reviews: The Krasnoyarsk Agglomeration, Russian Federation. Paris: OECD. 
Rodriguez-Pose, A. and Di Cataldo, M. (2015). Quality of government and innovative performance in the regions of Europe, In Journal of Economic Geography. 15(4), 673-706.

Rodrik, D., Subramanian, A. and Trebbi, F. I. (2002). Institutions rule: the primacy of institutions over geography and integration in economic development, In Journal of Economic Growth, 9, 131-165.

Ukaz Prezidenta RF ot 16.01.2017 № 13 “Ob utverzhdenii osnov gosudarstvennoi politiki regionalnogo razvitiia Rossiiskoi Federatsii na period do 2025 goda" [The Presidential Decree on January 16, 2017 № 13 “On the Approval of Fundamentals of the State Policy of Regional Development in the Russian Federation till 2025], In Ofitsialniy internet-portal pravovoi informatsii. Gosudarstvennaia sistema pravovoi informatsii [The Official Site of Legal Information. The State System of Legal Information]. Available at: http://pravo.gov.ru/laws/acts/4/4951.html

World Development Report 2009: Reshaping Economic Geography. Vol. 2. The International Bank for Reconstruction and Development/World Bank.

Zubarevich, N.V. (2015). Strategiia prostranstvennogo razvitiya posle krizisa: ot bolshikh proektov k institucionalnoi modernizatsii [The strategy of spatial development after crisis: from great projects towards institutional modernization], In Zhurnal NEA [Journal of the New Economic Assosiation], 2 (26), 226-230.

\section{Подходы к оценке взаимосвязи социально-экономического и инновационно-технологического развития, \\ а также институциональных условий \\ и процессов урбанизации ресурсных регионов \\ с использованием динамических \\ экономико-статистических моделей}

\section{А.Р. Семенова, Е.Б. Бухарова, И.М. Попельнитская, Н.В. Непомнящая, В.А. Разумовская Сибирский федеральный университет Россия, 660041, Красноярск, пр. Свободный, 79}

\footnotetext{
В зависимости от сложившихся условий, особенностей формирования тех или иных регионов, стратегических иелей пространственного развития страны и институциональной среды эффекты урбанизащии для социально-экономического и инноващчинно-
} 
технологического развития территорий неоднозначны. Цель выполненного исследования - оченить на основе сопоставимых статистических данных количественные индикаторы, характеризуюшие взаимосвязь процесса урбанизации и факторов экономического, инновачионно-технологического и сощииокультурного развития регионов с ресурсной экономикой.

В контексте методологии системного анализа урбанизированные территории рассматриваются как многокомпонентные сложные системы. Современные тенденции в практике прогнозирования, планирования и управления урбанизированными территориями направлены на поиск решения мультикритериальной многомерной задачи со сложной системой ограничений, которая, как правило, не детерминирована.

В работе рассмотрены подходы к моделированию взаимосвязи факторов социальноэкономического развития и уровня урбанизации городских поселений ресурсного региона (Красноярского края) и к оченке комплексного рейтинга урбанизированных территорий, основанного на динамическом изменении этих факторов.

Ключевые слова: ресурсная экономика, сочиально-экономическое и экологическое развитие урбанизированных территорий, пространственное развитие, комфортность проживания, динамическое экономико-статистическое моделирование, институциональные условия.

Исследование выполнено в рамках гранта «Методологические подходы к типологизации современных прочессов урбанизаџии территорий ресурсных регионов Сибири и моделирование влияния уровня ключевых факторов урбанизации на инновационнотехнологическое, экономическое и соииокультурное развитие региона (на примере Красноярского края)», № 17-12-24013.

Научная специальность: экономика. 